\title{
Original paper \\ Tectonic setting of the Ohře/Eger Graben between the central part of the České středohoří Mts. and the Most Basin, a regional study
}

\author{
Vladimír CAJZ1*, Jaroslav VALEČKA² \\ ${ }^{1}$ Institute of Geology, Academy of Sciences CR, Rozvojová 269, 16502 Prague 6, Czech Republic; cajz@gli.cas.cz \\ ${ }^{2}$ Czech Geological Survey, Klárov 3, 11821 Prague 1, Czech Republic \\ * Corresponding author
}

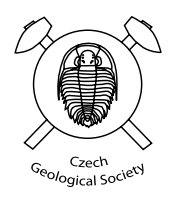

The paper presents the results of a new detailed survey in the SW part of the České středohoří Mts. (a section of the Ohře/Eger Graben/Rift), focused on its tectonic setting. Courses of the SE marginal graben faults are traced in detail. This limiting fault zone is described as a horst, with the graben fill being structured into rhomboidal blocks; older known faults are specified, and new faults are depicted. Respecting the age ranges of the preserved stratigraphic units, fault movements are classified into those older than $36 \mathrm{Ma}$, younger than $24 \mathrm{Ma}$ and younger than $16 \mathrm{Ma}$ (with a possible age less than $9 \mathrm{Ma}$ ), based on different lithologies and abrupt lithological changes (i.e., the rock boundaries). The faults are compared with the earlier defined paleostress fields. Fault reversals were detected on several faults. An important role of crystalline basement ridges during the graben formation was identified: three complex tectonic structures are spatially associated with these ridges. Two areas with distinct tectonic and geological development were defined within the Ohře/Eger Graben. The Saxothuringian - Teplá-Barrandian terrane boundary was found to be less important for graben formation during the Cenozoic. This disagrees with simplified riftogenic model of the Ohře/Eger Graben. The supposed "Litoměrice Deep-seated Fault", possibly representing a first-order terrane boundary, could not be confirmed in the post-Paleozoic rocks - this structure did not function as a fault during Cenozoic times.

Keywords: surface-detected faults, timing of tectonic activity, Ohře/Eger Graben/Rift, Bohemian Cretaceous Basin, České středohoři Volcanic Complex, Most Basin

Received: 28 May 2010; accepted: 15 September 2010; handling editor: V. Kachlik

\section{Introduction}

Since the papers of Kopecký $(1974,1978)$, the Ohře/Eger Graben has been believed to represent a rift structure. This idea was a modern one at its time; nevertheless, it has not been generally accepted. An unclear tectonic setting was one of the main reasons for rejection of the rift idea, especially by geologists with detailed knowledge from the field (e.g., Hurník and Havlena 1984; Malkovský 1987). Contrary to their opinion, the rift concept is accepted worldwide (Wilson and Downes 1991; Ziegler 1992; Dèzes et al. 2004; Haase and Renno 2008). Such situation calls for a regional research aimed at the character and timing of tectonic activity. This is one of the possible approaches which can contribute to better knowledge of the origin of this graben.

At present, the courses of fault zones limiting the Ohře/Eger Graben (EG) are generally well known. The direction of the České středohoří Fault Zone (CSFZ limiting the EG in the southeast) became better defined during the detailed survey on scale 1:10 000 (Šebesta et al. 1997; Valečka et al. 2003, 2008). The course of the Krušné hory Fault Zone (limiting the EG in the northwest) and the related movements were identified very well in the area of lignite mining.
Internal tectonic structure of the EG is still much less known compared to that of the limiting fault zones. Cajz et al. (2004) published newly discovered faults in the central and eastern parts of the České středohoří Volcanic Complex (CSVC) and Rajchl et al. (2009) clarified tectonic conditions during sedimentation of the Most Basin (MB) fill. This paper tries to combine these two separate areas inside the graben, presenting the results of a detailed survey from the region in between. It should be emphasized that the current study deals with tectonic deformations visible only in the post-Paleozoic sediments and volcanic products. Moreover, it is based on faults identified in outcropping geological units. It is not the aim of this paper to compare these structures with the supposed tectonic setting of the basement.

New faults were found in the area defined approximately by the cities of Bílina, Teplice, Ústí nad Labem and Lovosice, i.e., between the central part of the CSVC and the sedimentary fill of the MB (Fig. 1). The course of several faults belonging to the CSFZ was specified more precisely. The faults are vertical or very steeply inclined. Dip-slip faults were mostly detected, but strike-slip and combined movements are also present. Typically, some of the faults were reactivated several times during the history and the movements on their fault planes may 
have undergone reversals. Unfortunately, the fault planes could not be traced along their full length and only their near-surface segments are described.

Much of the volcanic material has been eroded from the studied region. Rocks of Variscan basement and Cretaceous sediments beneath the volcanics are exposed, being partly covered by sediments of the MB and by the youngest volcanic products. This setting is complicated by tectonic movements during the formation of nearly all geological units. The result of possible movements on the fault - i.e., the vector sum - can be determined based on the field survey and the evaluation of borehole data. The timing of the movements can be estimated from the age of the stratigraphic units deformed. The authors wish to emphasize that the vertical movement attributed to the individual faults and their parts is time-dependent and the total displacement magnitude as observed today only expresses the vector sum. Unfortunately, not all data necessary for an accurate interpretation are always available from the survey and borehole evaluation.

\section{Lithostratigraphic units used for fault detection}

Saxothuringian crystalline basement is exposed in the Oparno Valley, in the city of Bílina and its close surroundings and several isolated bodies are located south of the highest peak, Milešovka Hill. Carboniferous rocks are represented mainly by rhyolite deposited as a pyroclastic flow (ignimbrite) produced from the Teplice-Altenberg Caldera. Less frequent are conglomerates. These rocks are exposed especially in the Oparno Valley, covering the crystalline basement, and in the Bílina area.

Upper Cretaceous rocks are present in a complete succession described by Čech et al. (1980). Paleogene sediments have been preserved over a small area only. Volcanics of the CSVC are developed in all formations as defined by Cajz (2000) and Cajz et al. (2009). Sediments of the Most Basin are represented by sands of the Bílina delta. Typical fine-grained basinal sediments are developed as well, especially in the northern and northwestern part of the study area.

\subsection{Upper Cretaceous}

Facial and spatial development, together with the uniform thicknesses of the lithostratigraphic units described below, indicate tectonic stability of the study area during the Late Cretaceous sedimentation. The area got involved in the Bohemian Cretaceous Basin (BCB) mainly due to long-term rise of global sea level; subsidence played a subordinate role. This is in great contrast to the zone farther NE (closer to the Lusatian Massif) where a rapidly subsiding zone (depocentre) developed immediately at the beginning of sedimentation (Valečka 1989; Uličný et al. 2009a). In that zone, the thicknesses of sedimentary units increase almost by the factor of five. The exceptional tectonic stability came to an end in the Coniacian. Then, the study area was subjected to the same tectonic regime as the other parts of the $\mathrm{BCB}$. The relatively rapid and continuous subsidence resulted in high thicknesses of monotonous calcareous pelites of the Březno Fm.

The Peruc-Korycany Fm. (Cenomanian) consists of the Peruc and Korycany members. The Peruc Mb. (thickness max. $23.7 \mathrm{~m}$ ), filling only narrow depressions in the basement, is characterized by upwards-fining fluvial cycles. The cycles begin with sandstones or conglomerates and end with claystones, locally with high amount of organic matter. Sandstones of the Korycany Mb. (thickness max. $40-50 \mathrm{~m}$ ) cover a wider area but are missing at basement elevations.

The Bílá hora Fm. (Lower-Middle Turonian) (max. $73.5 \mathrm{~m}$ ) is mainly developed in the form of silicified spiculitic marlstones or spongolites ("opuka" in Czech). These rocks pass downward to mudstones, and to glauconitic, calcareous sandstones, 1-3 m thick, at the top of the formation. Near the Most-Teplice Elevation (see below), sandstones predominate, and shallow-water biosparitic limestones were locally deposited.

The Jizera Fm. (Middle-Upper Turonian) is represented by marlstones, less frequently by biomicritic limestones, $2.5-40 \mathrm{~m}$ thick. They progressively overlap the top of the Most-Teplice Elevation. In places, basal conglomerates with blocks of material abraded from local basement rocks occur at several levels, indicating several transgression phases (Čech and Valečka 1991).

The Teplice Fm. (Upper Turonian-Lower Coniacian) consits of alternation of marlstones and biomicritic limestones, representing a characteristic development; the thickness reaches $35-55 \mathrm{~m}$. In the lower part, the limestones concentrate to a sequence 7-12 m thick. A distinct basal bed with high glauconite content, phosphatic nodules, phosphatised fauna and coprolites, with a sharp, erosive lower contact represents a correlative horizon in the whole BCB.

Rohatce Member (Coniacian) - marlstones with hard, silicified limestone beds as a typical marker; max. thickness $25 \mathrm{~m}$. They occur in the eastern and central parts of the area. To the west, the hard beds wedge out and pass into marlstones.

The Březno Fm. (Coniacian-Lower Santonian) in the development of monotonous marlstones or calcareous claystones attains a complete thickness of 220-240 m.

The Merboltice Fm. (Santonian) occurs as relics of sandstones preserved only in the southern surroundings of Ústí nad Labem in max. thickness of 70-80 m. 
volcaniclastics of ol. basalts

olivine-free basalts

volcaniclastics of olivine-free basalts

phonolites and trachytes

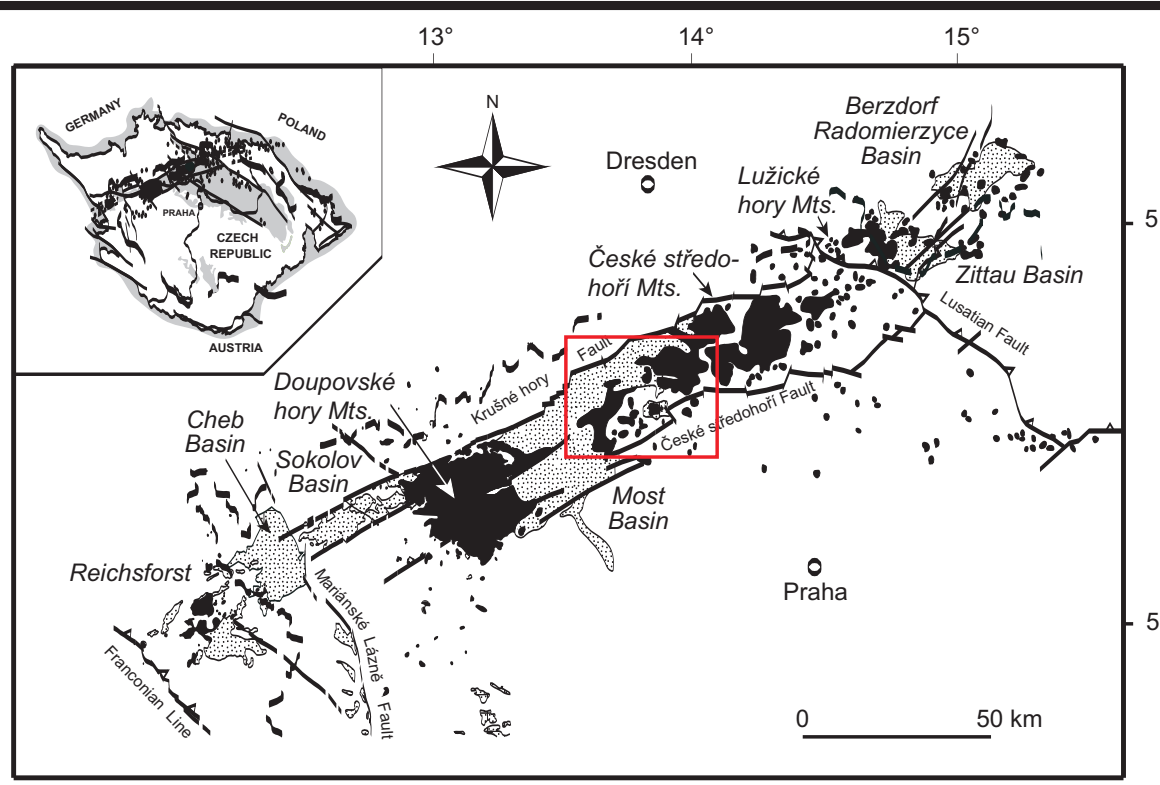

and the Most Basin, a regional study.

Usti nad
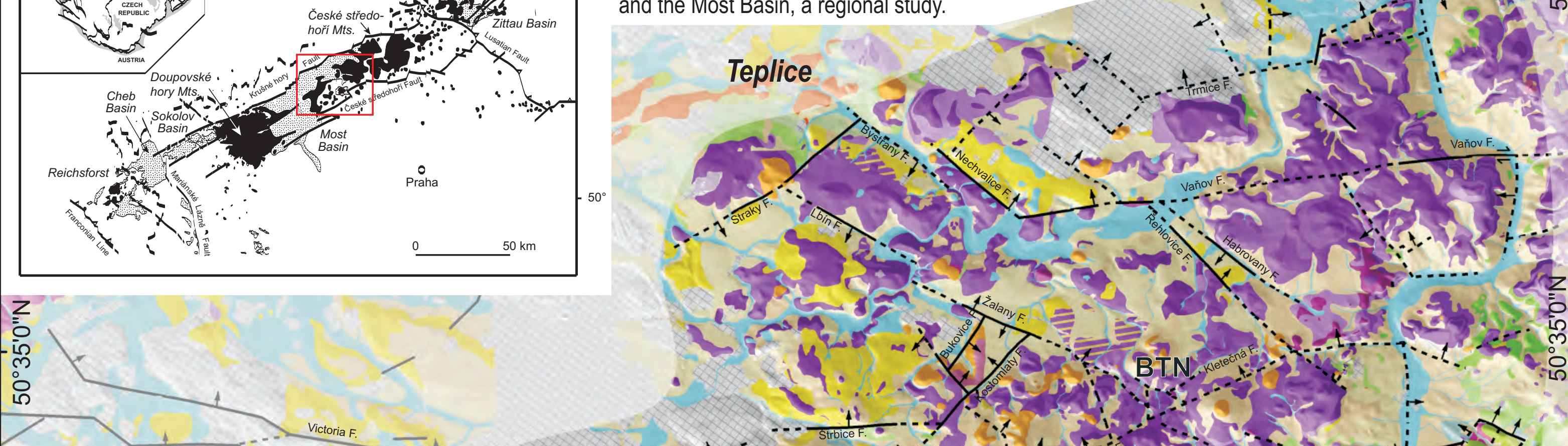

$3 \mathrm{~s}$ का
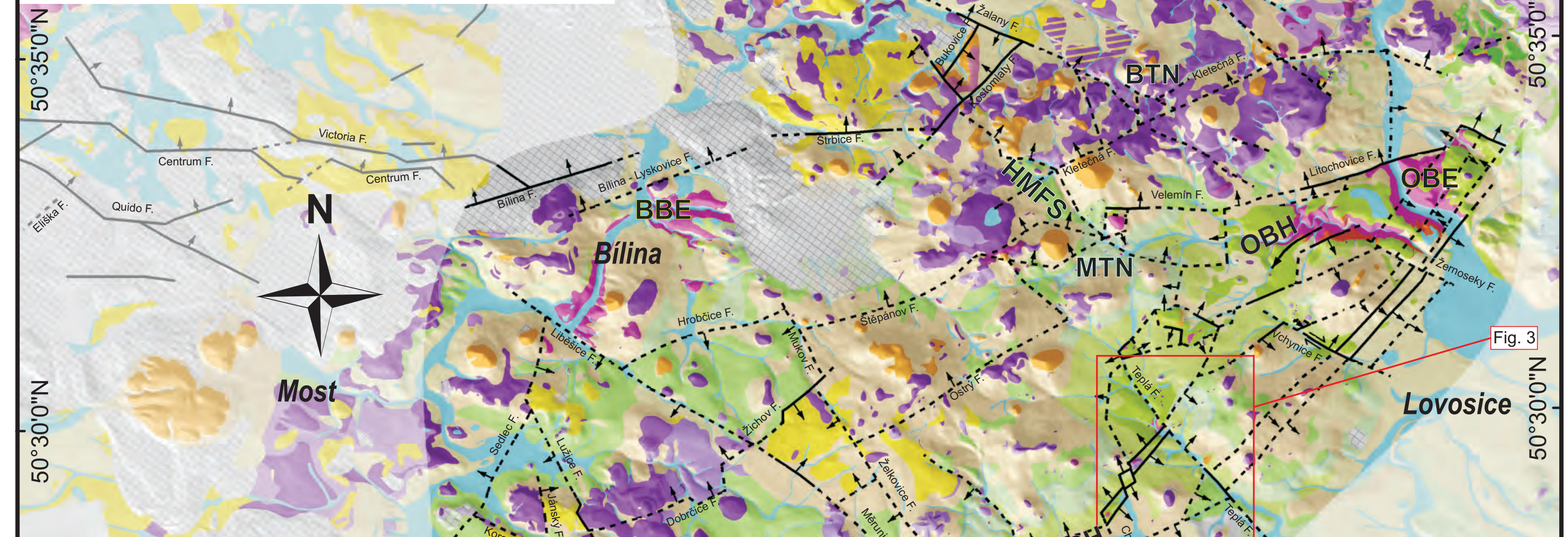

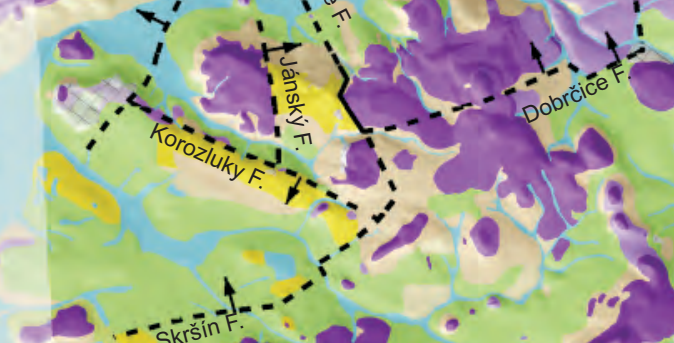

(1):
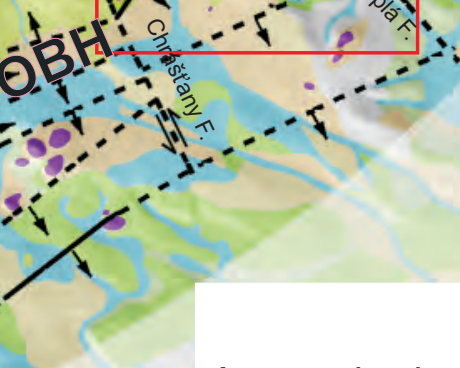

BBE - Bílina Basement Elevation OBE - Oparno Basement Elevation $\mathrm{OBH}$ - Oparno-Břvany Horst

BTN - Borislav Tectonic Node

MTN - Borislav Tectonic Node
MTN - Milešov Tectonic Node

HMFS - Hlince-Milešov
HMT Fault System
Fig. 1

A tectonic sketch of a geological map

from the new detailed survey

(Šebesta et al. 1997;

Valečka et al. 2003, 2008).

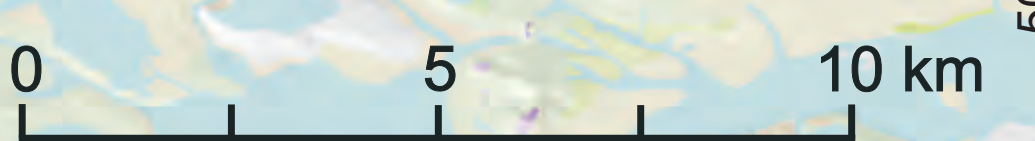

$10 \mathrm{~km}$

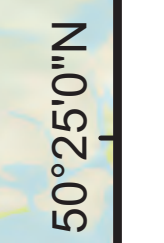
$14^{\circ} 0^{\prime} 0^{\prime \prime E}$ 


\subsection{Pre-volcanic Tertiary}

The Staré Sedlo Fm. (Paleogene) includes remnants of fluvial sediments of an ancient stream network. The drainage pattern was very different from the present one, transecting the course of the later formed Ohře/Eger Graben. Fluvially redeposited material of the Merboltice Fm. sandstones has been reported from Dolní Zálezly in the Labe/Elbe River valley (Šebesta et al. 1997). Relics of quartzites from several areas in the České středohoří Mts. and their close surroundings are supposed to represent a silcrete, i.e., a weathering product from hot climate in the Paleogene. In the study area, quartzites representing strongly silicified conglomeratic sandstones occur only near Lužice, overlying the Březno Fm. marlstones (Valečka et al. 2008).

\section{3. České středohoří Volcanic Complex}

The studied region is transitional between the central part of the complex and its margin in the Louny area. A different erosion rate can be presumed for the central and marginal parts of the complex. In addition, stratigraphy of volcanic units is more complicated than that of Cretaceous sediments, showing much less continuity. Longer periods of volcanic quiescence occurred between the depositions. The time spans of the two oldest formations partly overlap, which is caused by problems of $\mathrm{K}-\mathrm{Ar}$ dating method and evaluation of its results: geological criteria show a different relationship. It is important for the survey that the two formations are easily recognizable and obey the Principle of superposition. Only the phonolitic intrusions are problematic because they may belong to either of the two oldest formations. They are, however, not fundamental in fault detection. As all these units are of continental origin, the erosion destroyed their rocks continuously during dormant periods but also during the volcanic activity. Moreover, the study area is unique by the presence of the youngest volcanic activity subsequent to the basin fill sedimentation (Cajz et al. 2009).

Ústí Fm. (Uppermost Eocene-Lower and Middle Oligocene; 37-28 Ma) - basanitic volcanism produced mostly into water environment (syngenetic alteration) includes sedimentary intercalations (with diatomites and lignite), fault-controlled vents and occasional terrestrial volcanoes of Strombolian type. Effusive products covered large areas in general.

Děčín Fm. (Middle and Upper Oligocene; 31-25 Ma) - tephritic to trachybasaltic terrestrial volcanism, large central composite volcano, many parasitic vents over a wide area, explosive and effusive activity (stratovolcanic style). Explosive and effusive products covered large areas but only remnants are present now.
Dobrná Fm. (Upper Oligocene-Lower Miocene; 24-19 Ma) - scattered Strombolian volcanoes of basanitic production. They were spread across the CSVC and beyond; only vents and relics of cinder cones and lavas survive.

Štrbice Fm. (Middle and Upper Miocene; 13-9 Ma) - isolated, mostly Strombolian volcanoes of basanitic chemistry and their subvolcanic apparatuses concentrated in the study area. The youngest volcanism of the CSVC.

\subsection{Sediments of the Most Basin}

Střezov Fm. (Paleogene-Neogene). A lithological definition as volcanic, volcaniclastic and mixed volcaniclastic and sedimentary material below the Most Fm. is too wide, as is the stratigraphic extent. The rocks of this formation originated by weathering and transport of CSVC volcanics, and by rare volcanic activity in the area of the MB. They can be paralleled with the Ústí, Děčín and partly with Dobrná formations of the CSVC.

Most Fm. (Neogene) - we substitute this regular stratigraphic term by informal "sedimentary or basin fill". We do not subdivide the formation into members and we do not distinguish separate lithofacies as it is not necessary for our tectonic considerations.

\section{Pre-Cretaceous relief and Late Cretaceous sedimentation}

In the relief of the basement, two positive morphological forms with no sedimentation of the Peruc-Korycany Fm. can be recognized: the Oparno and Bílina basement elevations (Fig. 2). These elevations, developed already in some form before the sedimentation, strongly influenced the spatial distribution, thickness and lithofacies development of the Peruc-Korycany, Bílá hora and Jizera formations. These elevations are present in the area of the Bílina Block which is defined in the basement (sensu Mlčoch ed. 2001). In further text, we use names for these elevations - parts of basement outcrops because the morphological function of these older structures was very important for Cretaceous sedimentation. Both of them are parts of previously described larger structures in the basement.

The eastern Oparno Basement Elevation (OBE) is elongated in the WNW-ESE direction. It is a relatively low elevation characterized by a progressive, slow transgression of the Bílá hora Fm. The thickness of the transgressive Bílá hora Fm. attains only $1 \mathrm{~m}$ on top of this elevation. Far to the east from the Elbe River, the OBE continues as the Litoměřice-Maršovice-Bezděz Elevation (Vejlupek 1984; Vejlupek and Novák 1986). To the $\mathrm{W}$, the OBE is linked with the Most-Teplice Elevation (Čech and Valečka 1991). 


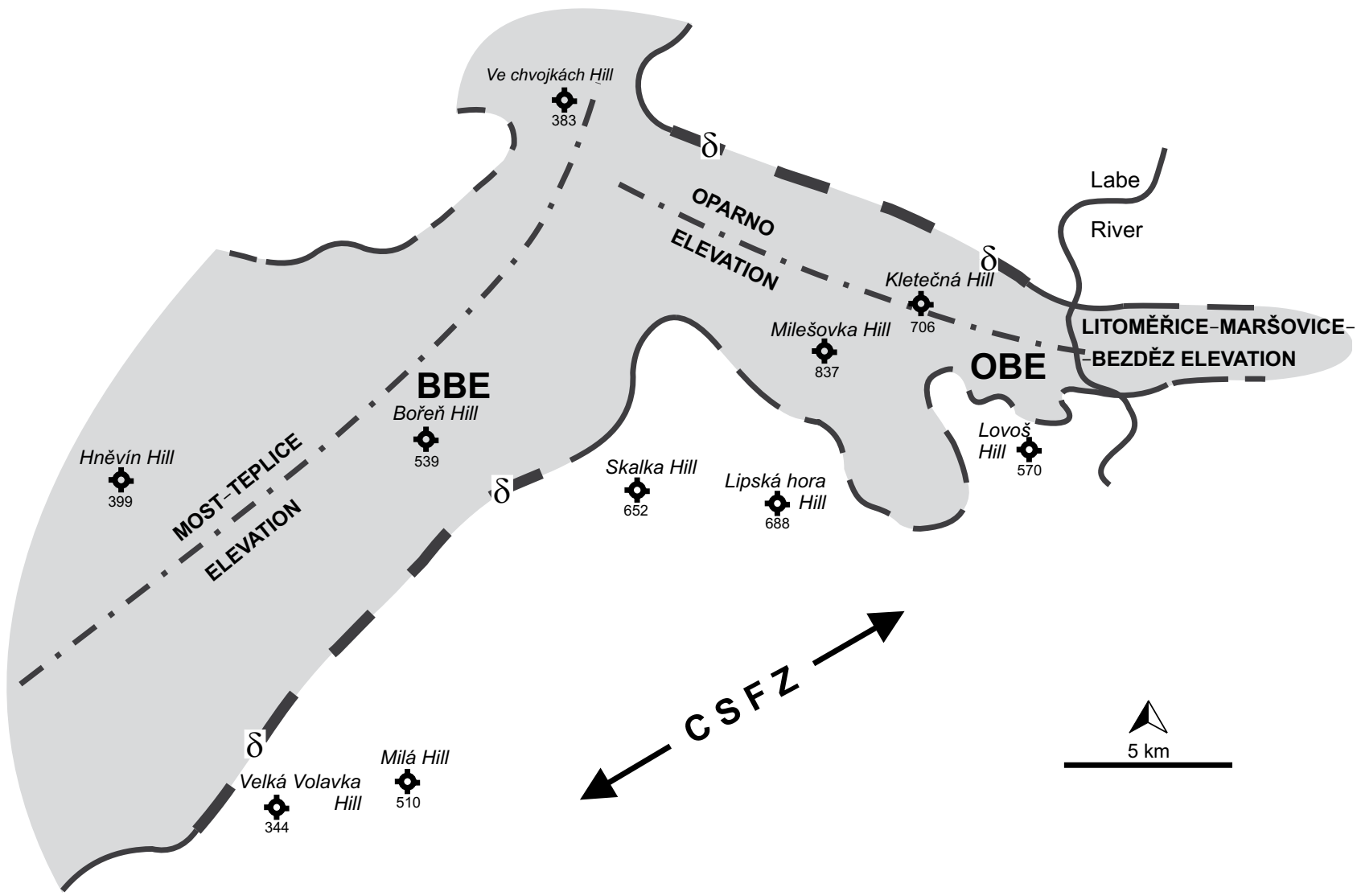

Fig. 2 Basement elevations below Cretaceous sediments. Most-Teplice and Oparno elevations boundaries: dot-and-dash line - elevation axes; grey - area of an "island" during the Peruc-Korycany Fm. sedimentation; thick dashed line with a $\boldsymbol{\delta}$ symbol - elevation margins of (old ?) tectonic origin. BBE - Bílina Basement Elevation, OBE - Oparno Basement Elevation, CSFZ - České středohoři Fault Zone.

The Most-Teplice Elevation is elongated NE-SW; it was the highest elevation in the entire BCB. Its upper part is covered by the Jizera Fm. marlstones, thickness of which is reduced to $2.5 \mathrm{~m}$ on the top. The uncovered part of the Most-Teplice Elevation near Bílina is herein called the Bilina Basement Elevation (BBE). Its SE slope is relatively steep, possibly of tectonic origin. At the foot of the slope, a narrow depression (paleovalley) is situated with fluvial fill of the Peruc Mb. The depression is elongated in the NE-SW direction. A similar depression with the Peruc Mb. (Stebno paleovalley sensu Uličný et al. 2009b), oriented W-E or WNW-ESE, is present near the northern margin of the OBE, indicating its possible tectonic character.

\section{Tectonic development during the latest Cretaceous and earliest Tertiary}

No Cretaceous sediments younger than the Merboltice Fm. sandstones (Santonian) are present either in the study area or in the BCB. The development before the deposition of the Staré Sedlo Fm. (Paleogene) is therefore dif- ficult to assess: it was dominated by erosion. Data from the central part of the CSVC suggest that the Paleogene fluvial sediments are composed of the same material as the Santonian sandstones. Fluvial re-deposition possibly resulted in a relative increase in kaolin proportion in the sediment in some areas. Unfortunately, the Staré Sedlo $\mathrm{Fm}$. sediments are rare in the area of the CSVC, and the reconstruction of the drainage pattern is thus impossible.

Superficial rocks of the CSVC overlie the Cretaceous sediments, especially those of the Merboltice and Březno fms. In the study area, relics of the Merboltice Fm. sandstones, max. 50-70 m thick, are limited to a small area $\mathrm{S}$ of Ústí nad Labem. Almost as a rule, superficial rocks of the CSVC overlie the monotonous claystones of the Březno Fm., preserved commonly in the thickness of 60 to $120 \mathrm{~m}$, so the identification of tectonics is very problematic. The nearly total erosion of the Merboltice Fm. sandstones and the erosion of a large part of the Březno Fm. claystones contrast with the central part of the CSVC where great volumes of these sandstones are preserved in thicknesses of up to $200 \mathrm{~m}$. It can be therefore assumed that the relative tectonic uplift of most of the study area occurred before the onset of volcanic activity. Tectonic 
style with rhomboidal blocks, similar to that detected in the central part of the CSVC (Cajz et al. 2004), can be supposed. This tectonic activity was followed by a long period of peneplanation, leaving no sedimentary record. The peneplanation created flat morphology with shallow depressions, due to the stream network draining the area. This time was coeval with the deposition of the Stare Sedlo Fm. Superficial rocks of the CSVC therefore overlie the Cretaceous sediments with a flat or only slightly inclined topography. Tectonic disintegration into blocks can be deduced from the erosion intensity of Cretaceous sediments preserved below the superficial volcanic products of the CSVC. The borehole data evaluation resulted in the definition of two large tectonically contrasting areas resulting from pre-volcanic tectonic activity.

The beginning of volcanism was accompanied by the onset of another phase of tectonic activity. Low topography in the central part of the CSVC caused the presence of water reservoirs - most probably shallow lakes as a part of a drainage system. This was the host environment for primitive magmas of the Ústí Fm. The most subsided area was situated approximately between the Ploučnice Fault (F.) in the NE (beyond the study area) and a line between the OBE and BBE in the SW. This area can be understood as the real central part of the CSVC: it represents the oldest Tertiary depocentre in the graben, situated transverse to the EG course. Volcanism of the Ústí Fm. was accompanied by continued tectonic activity. Formation of deep and narrow syn-volcanic depressions is known at several places (Cajz et al. 2004).

\section{Description of individual faults}

The tectonic scheme drawn in a geological map (Fig. 1) is based on a new detailed survey and evaluation of borehole data. Generally, the structures can be subdivided into faults pertaining to the CSFZ in the SE and other structures of the internal part of the graben. Alternatively, they can be subdivided into parallel and transverse ones relative to the general graben course.

\subsection{Faults parallel to the general Ohře/Eger Graben course (ENE-WSW)}

\subsubsection{Faults of the CSFZ}

Müller (1924) for the first time, and consequently Hibsch (1926), coined the term České středohoří Fault to describe the single but morphologically prominent tectonic structure apparently limiting the České středohoří Mts. in the SE. Later, this term was used by Malkovský (1977, 1979). The same fault was named Litoměrice Fault by Váně (1985, 1999) and Herčík et al. (2003). Štovíčková et al. (1973), Kopecký (1978) and Malkovský (1979) considered this fault to represent the epitectonic manifestation of an old suture in the crystalline basement (the Saxothuringian - Teplá-Barrandian terrane boundary), designated as "Litoměrice Deep-seated Fault". Similar idea was invoked by Pešek (1996) to explain the supposed northern tectonic limit of the Permo-Carboniferous sedimentary basins underlying Cretaceous sediments. Moreover, the rift concept of the EG (Kopecký 1978) was based on the existence of this deep structure and especially on its activation during the Cenozoic. Lastly, Cháb (2008) assumed the České středohoří Fault and the Ohře Fault, or a Fault Zone (more to the SE), to represent tectonic manifestations of the "Ohře/Eger Rift".

Our new detailed survey proved the existence of a complicated fault zone on the SE foot of the České středohoří Mts., but its origin can be hardly connected with rifting as directly as has been assumed. We use the term České středohoři Fault Zone, but we describe its course in a considerable detail and decipher its different tectonic development. This structure only very generally parallels the České středohoří or the Litoměřice faults of previous authors. We traced the course of the CSFZ from the valley of the Labe/Elbe River between Lovosice and Litochovice in the NE to Břvany in the SW (see Fig. 1). The zone consists of four to six parallel or nearly parallel faults, and is intersected by several younger transverse faults. The CSFZ strikes NE-SW between the Labe River valley and Třebenice; far to the $\mathrm{SW}$, the strike changes for ENE-WSW. The width of this zone is very high in the $\mathrm{E}$ ( $5 \mathrm{~km}$ between Velemín and Lovosice) but decreases to $2.5-3 \mathrm{~km}$ in the SE. Some faults in the zone branch off, some vanish. The vertical displacement of the southern blocks is very moderate, reaching a few tens of meters only. The CSFZ is an asymmetrical structure. Blocks uplifted to the highest tectonic position in the whole area concentrate only approximately along the northern border of the CSFZ, forming a horst structure. We call this structure the Oparno-Brvany Horst (OBH). The uplifted blocks of the OBH are composed of spiculitic marlstones and spongolites (opukas) of the Bílá hora Fm., locally with relics of the Jizera Fm. marlstones. In some blocks in Oparno-Velemín area, gneisses and migmatites of the Krušné hory/Erzgebirge Crystalline Complex (Saxothuringian Zone) are exposed beneath Carboniferous rhyolitic ignimbrites and Cretaceous opukas. The strike of the OBH does not follow the course of the CSFZ in detail, it coincides only very generally. The width of the OBH is $1.5-1.7 \mathrm{~km}$ between the Labe River valley and Velemín, in a segment striking ENE-WSW. The strike of the OBH turns to NE-SW between Velemín and Podsedice, with the width locally reduced to 100 $\mathrm{m}$. In this part, the $\mathrm{OBH}$ is fragmented into many small blocks, displaced by transverse strike-slip faults (Fig. 3). 


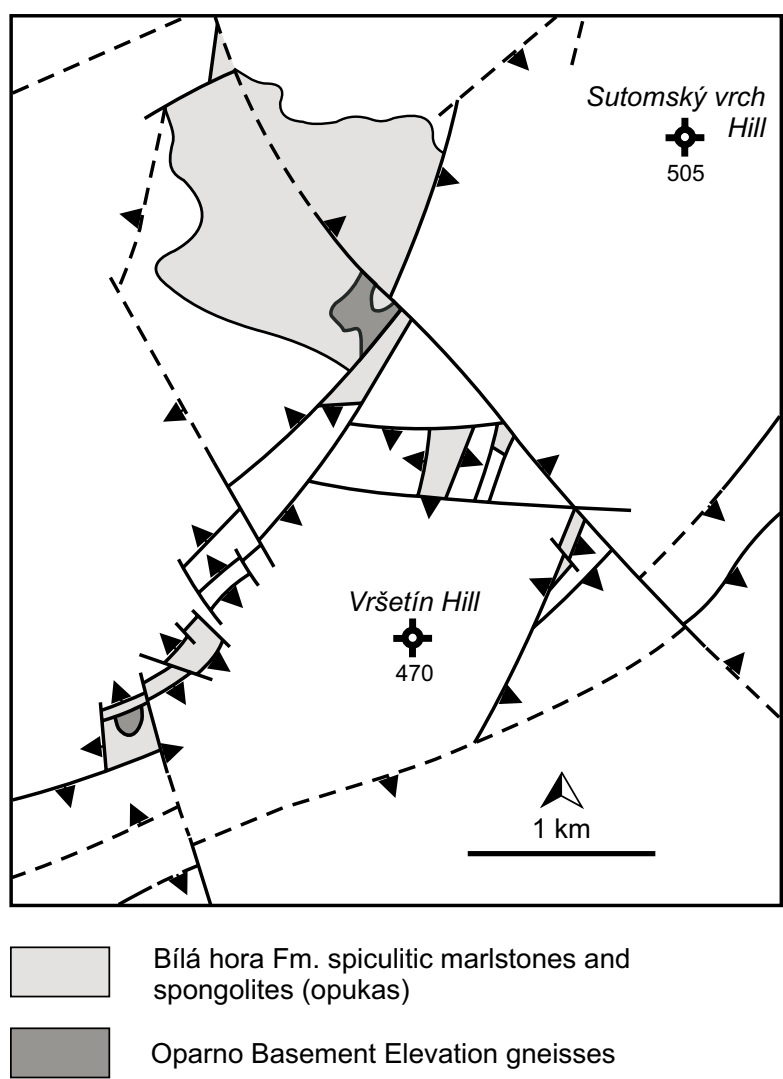

Fig. 3 Detail of the Oparno-Břvany Horst (OBH) in the surroundings of Vlastislav.

At Podsedice, the horst merges with the common course of the CSFZ, returning to the ENE-WSW strike. In the segment between Podsedice and Břvany, the structure of the CSFZ is simpler, consisting of only two border faults. The $\mathrm{OBH}$ is one of the most prominent tectonic structures in the study area. Only its part near Břvany has been described before: Váně (1999) reported an uplifted "horst-like" block limited by the Břvany and Hrádek faults, having a width of up to $2.5 \mathrm{~km}$. We adopted these names for the border faults of the OBH along most of its course between Břvany and the Vlastislav-Teplá area. Between the Labe River valley and Velemín, the border of the OBH is linked with the Litochovice $\boldsymbol{F}$. (Vejlupek and Kaas 1986) and the newly documented Chotiměr F. (Kycl et al. 2009). On the Litochovice F., relative subsidence of the northern block attains the highest value - approx. $150-200 \mathrm{~m}$. This is the place, where the strike of the OBH is parallel to the axis of the OBE in the basement. In the Velemín area, the horst departs from this elevation generally to the $\mathrm{S}$ and proceeds as far as to Trrebenice. From Třebenice to the $\mathrm{W}$, the horst strikes ENE-WSW again. From Velemín, relative subsidence of blocks $\mathrm{N}$ and NW of the OBH decreases to several tens of meters only. The high vertical displacement magnitude on the Litochovice F. splits into several faults of different strikes. This very complicated point is herein called the Milešov Tectonic Node (MTN).

The general strike of the CSFZ only partly coincides with the "Litomerrice Deep-seated Fault" idea. The detailed course of the OBH is completely different from the latter. This is why we cannot agree with the simplified model of tectonic setting of the graben, which led to the rift concept. We only agree with the idea of Pešek (1996), in which the southern border of the CSFZ coincides - for some fault segments - with the tectonic boundary of Permo-Carboniferous sedimentation and the Saxothuringian Crystalline basement. To the SW of Charvatce (beyond the study area), the CSFZ runs several kilometers to the north of this older tectonic boundary.

\subsubsection{Faults inside the Ohře/Eger Graben and parallel to its course}

This subgroup can be divided into semi- and subparallel faults. The most important semiparallel fault is the Litochovice $\boldsymbol{F}$., described above as the northern limit of the $\mathrm{OBH}$ in the OBE area. This is the fault with the largest vertical displacement in the whole study area, functioning as the southern limit of the oldest Cenozoic depocentre of volcanic products. Its continuation, the Velemín F. (as far as to the MTN), is ranked among transverse faults due to its E-W strike. The subparallel Štěpánov $\boldsymbol{F}$. represents the next continuation to the SW but its vertical displacement magnitude reaches only $50 \mathrm{~m}$ now, which is caused by younger movement of opposite sense detected in the volcanics. Farther to the SW, a fault of the same strike the Hrobčice F . - shows a subsided southern block and limits the area of crystalline rock outcrops SE of Bílina. Farther S and SW, the subparallel Skršín F . and Dobrčice $\boldsymbol{F}$. were detected with subsided northern blocks. The Žichov F . of the same strike shows an opposite sense of the sum of movement. The displacement magnitudes on these faults are several tens of meters. These three faults were formerly supposed to represent only a single one, which was called the Skršín F. over a larger distance (Valečka and Zelenka 2008).

Very important is the subparallel Kostomlaty $\boldsymbol{F}$. (see also below) which limits a rhomboidal and relatively small block of the Děčín Fm. volcanics, uniquely preserved in this area, which deeply subsided at the times of volcanic activity. An equivalent fault limiting this block from NW is the Bukovice $\boldsymbol{F}$. Another important subparallel Straky $\boldsymbol{F}$. is situated in the NW part of the study area, limiting basinal sediments in the NW. Other parallel faults are located in the northern part of the area and their strike and displacement are mostly constructed from borehole data evaluation. Among these, the Trmice $\boldsymbol{F}$. should be mentioned as the longest of the detected structures. 
Ostrý $\boldsymbol{F}$., which separates the vent and the cinder cone of the youngest volcano from its lava plateau, is characterized by a displacement of a few tens of meters with an uplift of the northern block. This fault movement ranks among the youngest in the area. This structure was activated much earlier with an opposite sense of movement. It forms the NW limit of a block with the most strongly eroded Březno Fm. claystones. The last structure worth mentioning is the Kletečná $\boldsymbol{F}$., which is covered by debris, material of slope movements and loess and thus difficult to detect on the surface. It runs across NW foothills of Kletečná and Milešovka hills with subsided NW blocks in the very complicated area of the Borrislav Tectonic Node (BTN). The course of the Kletečná Fault and tectonic reversals in its history were detected from borehole data. Pre-volcanic movements were characterized by a subsidence of the southern block, while the synor post-volcanic movements of even higher magnitude featured a subsidence of the northern block. The currently detectable displacement magnitude is nearly $150 \mathrm{~m}$.

\subsection{Faults transverse to the course of the Ohře/Eger Graben}

\subsubsection{Faults striking generally NW-SE}

These faults in the CSFZ strike nearly perpendicular to its course, causing lateral offsets in either direction. The most important ones are (from the SW to the NE): the Merrunice $\boldsymbol{F}$. limiting one of the larger OBH blocks, with a subsided SW block. It continues to the NW with this block uplifted due to younger movement. Its further continuation is the Liběšice $\boldsymbol{F}$. (sensu Valečka and Zelenka 2008) with an inverted movement of the sunken SW block. This part of the Liběšice F. can be synonymized with the Želenice F. of Zahálka (1914). The Želkovice F. (sensu Valečka and Zelenka 2008) limits the OBH with a subsided SW block; it continues to the NW as the newly detected Mukov $\boldsymbol{F}$. with the resulting opposite sense of movement. The Chrást'any $\boldsymbol{F}$. and the Teplá $\boldsymbol{F}$. form the limits of the narrowest, further segmented block(s) of the OBH in a similar manner. Their continuation to the NW was impossible to detect. The Vchynice $\boldsymbol{F}$. and the Žernoseky $\boldsymbol{F}$. offset the OBH very close to the OBE with a more easily detectable strike-slip movement (see Fig. 1).

Other transverse faults were detected in the central part of the graben. A complicated structure is typical of the westernmost part of the study area. The NNE-SSWstriking Sedlec $\boldsymbol{F}$. was activated in at least two periods, with opposite senses of movement. The Lužice $\boldsymbol{F}$. and the Korozluky $\boldsymbol{F}$. limit the extent of basinal sediments, the Lužice $\boldsymbol{F}$., together with the parallel Jánský $\boldsymbol{F}$., constitute a micrograben in volcanics where porcelanites (basinal sediments with a coal seam exposed to subaerial weathering) are preserved. In the centre of the study area, the Hlince-Milešov Faults System (HMFS) is developed between the MTN and the Kostomlaty F., moreover crossing the Kletečná F. Unfortunately, no magnitudes of the relative subsidence of NE blocks on the HMFS are available. Farther to the N, the Lbin $\boldsymbol{F}$. with the NE uplifted block and the Žalany $\boldsymbol{F}$. with the SW uplifted block limit the extent of the basin fill. The Žalany $\boldsymbol{F}$. terminates a deeply subsided volcanic block near Bukovice, as well. The NW-SE-striking Bystrany $\boldsymbol{F}$. and the Nechvalice $\boldsymbol{F}$. constitute a horst-like volcanic block uplifted from basinal sediments. In contrast, the $\mathbf{R}$ ehlovice $\boldsymbol{F}$. and the Habrovany $\boldsymbol{F}$. constitute a micrograben of the same trend filled with basinal sediments preserved among blocks with much older volcanics. Both faults possibly terminate at the Vaňov F.

In the Labe/Elbe River valley, several faults or segments of N-S strike were detected. They possibly determine the course of the river. Among them, only the Prackovice F. is important with the E block subsided by nearly $100 \mathrm{~m}$. Other faults do not show any important vertical displacement, but rather a strike-slip component.

\subsubsection{E-W trending faults}

Faults of this trend were responsible for the Neogene formation of depocentres in the Most Basin (Rajchl et al. 2009). In the studied region, they are present but much less frequent than described from the neighboring area by the same authors. The Bilina Fault is supposed to represent one of the most important structures of the region. Unfortunately, this term has been used in different sense. The structure of the Bílina "Crevasse" was first described by Zahálka (1914) as an E-W-striking fault south of the town of Bílina with only $20 \mathrm{~m}$ vertical throw and a short along-strike length of max. $2 \mathrm{~km}$. Hibsch (1924) used the name Bílina-Lyskovice $\boldsymbol{F}$. for a supposed fault limiting the extent of crystalline rocks and striking ENE-WSW, possibly running across the town of Bílina. Only two segments of this supposed fault are shown, $4 \mathrm{~km}$ apart, on the map of Hibsch (1924). It was proposed to separate the southern crystalline block from deeply subsided northern block with preserved Cretaceous and Miocene sediments. Later, during mining activities, the Bílina F. was indeed detected north of Bílina. It strikes ENE-WSW with a subsidence of the northern block by about $70 \mathrm{~m}$ (or up to $100 \mathrm{~m}$ ) as far as to its junction with the E-W-striking Victoria Fault (old miners' name). From this point on, both faults show a subsidence of the northern block by only $35 \mathrm{~m}$ farther to the W or WSW. The Centrum F. (old miners' name), which is subparallel to the Victoria F., shows similar vertical displacement. The split of a large vertical displacement magnitude on one fault into several 
faults with smaller throws is a situation analogous to that we have encountered at complicated tectonic points - tectonic nodes. Some authors (e.g., Brus and Hurník 1988; Rajchl et al. 2009) supposed an E-W strike of the Bílina F. The confusion in the definition of the strike comes possibly from Hibsch's text (1924) - “... the Bilina F. is accompanied by several $E-W$ trending faults ..." - or from the general course of a suspected hidden structure (Mlčoch ed. 2001). In the latest printed map, Kopecký ed. (1990) considered the Bílina F. as running from Braňany to the northern environs of Bílina, with generally ENEWSW strike. These authors described several faults (a fault zone) striking ENE-WSW and E-W as the Bílina Fault. Valečka (1990) suggested a continuation of the Bílina F. far to the E, as far as to the Labe River valley, evaluating boreholes in the Cretaceous sediments. The $\mathrm{E}-$ W-striking Bílina F. in the present concept runs farther to the E, forming an important tectonic structure in the basement (Mlčoch and Konopásek 2010). Unfortunately, it is impossible to track this fault in the volcano-sedimentary cover in the same way. Only our Štrbice F. and Velemín $\boldsymbol{F}$. follow this direction over a relatively short distance. They both have deeply subsided northern blocks (over $100 \mathrm{~m}$ ). Farther to the E, the Strbice F. terminates at the Kostomlaty F. - the high values of vertical displacement can be tracked in a different strike subparallel to the graben axis.

Another important E-W structure was described as the Van̆ov F. (Cajz et al. 2004). In the Labe/Elbe River valley, the right-lateral strike-slip movement prevails on its planes and the effects of faulting are partly responsible for present slope movements in the river canyon. A similar situation is encountered where this fault reaches the Bílina River valley. Far to the W, this fault continues with a more distinct vertical displacement and a subsided northern block. An indication of a tectonic reversal during the fault history is locally present.

The formerly described Žim F. (Cajz et al. 2004) is better visible with an E-W strike on the left bank of the Labe/Elbe River. It can be followed for several hundred meters to the west, before it merges with the semiparallel Kletečná Fault. The N-S course of the river changes for the E-W in Ústí nad Labem. This is caused by a leftlateral strike slip along an $\mathrm{E}-\mathrm{W}$-striking fault with some vertical component. It splits a phonolite laccolith into the Mariánská skála Hill and the Kamenný vrch Hill parts (Ulrych et al. 2000).

\section{Zones of largest vertical displacement and conclusions for riftogeny}

The question of the position of the possible "rift margin", i.e. that of the largest-magnitude normal faulting, is very difficult to answer. In any case, it does not follow the terrane boundary where "the main deep-seated fault driving the rift development" (sensu Kopecký 1974 and others) has been expected. The Litochovice $\boldsymbol{F}$. with the largest known vertical displacement (min. 150-200 m) is semiparallel to this boundary and follows the $\boldsymbol{O B E}$ better (Fig. 4). Its continuation, the Velemin $\boldsymbol{F}$., is transverse (E-W) and this highest value is detectable as far as to the MTN only. From here, the Štěpánov $\boldsymbol{F}$. with a younger reduced vertical displacement magnitude continues semiparallel to the central part of the EG and disappears at the $\mathrm{Mu}$ kov Fault. From the $\boldsymbol{M T N}$, the $\boldsymbol{H M F S}$ with NE subsided blocks is developed. The $\boldsymbol{H M F S}$ can be tracked as far as to the Kostomlaty $\boldsymbol{F}$. (with NW deeply subsided block, min. $100 \mathrm{~m}$ ) and is connected with the Strbice $\boldsymbol{F}$. (subsidence of northern block well exceeding $100 \mathrm{~m}$ ). The Štrbice Fault follows the Bílina F. of modern definition in the basement (e.g. Mlčoch 2003; Mlčoch and Konopásek 2010) in the limitation of the Bílina Block.

Both these complicated orientations of the largest dip-slip are problematic from the viewpoint of the "rift course". The only structure roughly conformable with the "rift course" is the $\boldsymbol{O B H}$ (see Fig. 4). The subsidence of northern blocks was, however, very modest, reaching several tens of meters, much like at the CSFZ itself. Moreover, another zone of large vertical displacement magnitude $(c .100 \mathrm{~m})$ is present, transverse to the graben axis. It is the $\check{Z}$ alany $\boldsymbol{F}$. connected with the Kostomlaty $\boldsymbol{F}$., which are situated in the central part of the graben.

The movements on any deep structures responsible for the graben formation must be traced superficially, in the exposed rocks older than the tectonic remobilization. From this detailed study we can conclude that for the formation of the graben with Cenozoic volcanic infill was the existence of the Oparno and Bilina basement elevations much more important than the presence of the Variscan terrane boundary. This study permits to define two separate areas, distinct in their geological development, at least during the Cenozoic. The border between them is formed by a wider $\mathrm{E}-\mathrm{W}$-striking zone represented by the $\mathrm{OBE}$ in the $\mathrm{E}$, and the $\mathrm{BBE}$ in the $\mathrm{W}$. This zone can be paralleled with the basement Bílina F. (sensu Mlčoch and Konopásek 2010). In the general direction to the $\mathrm{N}$ to ENE of this border, deeply sunken areas are filled with products of the oldest volcanism. A very moderately subsided area in a shape of "dish" is present generally to the S to WSW. In terms of riftogeny, only the approximate course of the CSFZ (with SE dips on subparallel faults) may express the possible upwelling during the rift formation with some "deep-seated" structure partly involved. Thus, the importance of the CSFZ as a manifestation of any deep-seated structure seems to have been overestimated. 


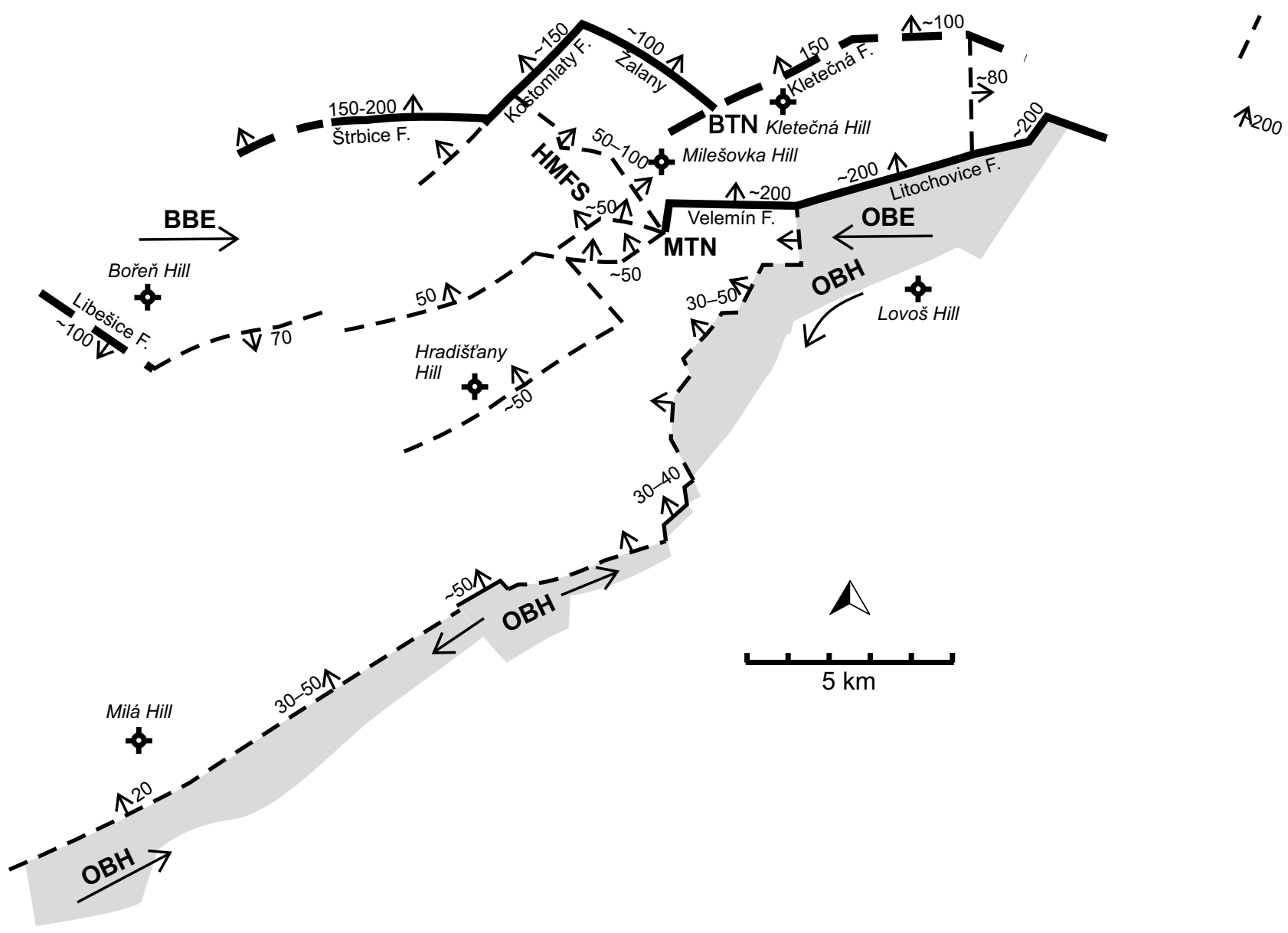

Fig. 4 Graben-forming faults: Oparno-Břvany Horst (OBH) - its highest blocks in grey; Oparno Basement Elevation (OBE); Bílina Basement Elevation (BBE). Also shown are tectonic nodes of Milešov (MTN) and Bořislav (BTN), as well as the complicated Hlince-Milešov Faults System (HMFS). The largest vertical displacement magnitudes on faults limiting the graben are given in meters. Arrows - resulting relative vertical movement of blocks (vector sum); arrow in the subsided block.

\section{Timing of tectonic activity}

Brittle deformation structures offset different stratigraphic units, which gives information on the age of the tectonic activity. This is, however, not exact enough. We also evaluated borehole data providing information on older movements, assuming that the stratigraphic unit is covered by a younger one. Other criteria are represented by paleogeomorphology and lithology of both sediments and volcanics. These are the reasons which permitted us to group the faults by the detected or assumed age into three groups. On the other hand, we know that the use of such criteria should be taken as a very rough time constraint only.

A) post-Cretaceous/pre-volcanic faults (Fig. 5) - formed before the volcanic activity, some of them being almost coeval with the onset of the volcanic activity. This group includes faults of the CSFZ and of the OBH. We believe that these "limiting" faults are older ones, with the major movements taking place prior to volcanic activity. Only the SE-dipping faults of the CSFZ may be partly caused by the subsequent possible upwelling of the region. Transverse faults segmenting both these structures are younger. Reaching the Labe/Elbe River, the strike of the CSFZ - parallel to the axis of the OBE - turns to the $\mathrm{E}$. The existence of the basement ridge played an important role. The Litochovice F. is situated above the northern steep slope of the OBE which may be of (older?) tectonic origin as well. In its continuation, the Velemín and Štěpánov faults possibly also represent products of pre-volcanic tectonic activity. We therefore suppose their formation simultaneous with the CSFZ.

Faults with the largest dip-slip of the northern (NE to NW) blocks (see Fig. 4) can be assigned to this group, as well. They could have been partly coeval with the onset of volcanic activity. These faults are situated inside the graben. Based on the detected erosion of Cretaceous cover on the OBE, it can be assumed that the activity of the Strbice (Bílina) F. also started at about the same time. 


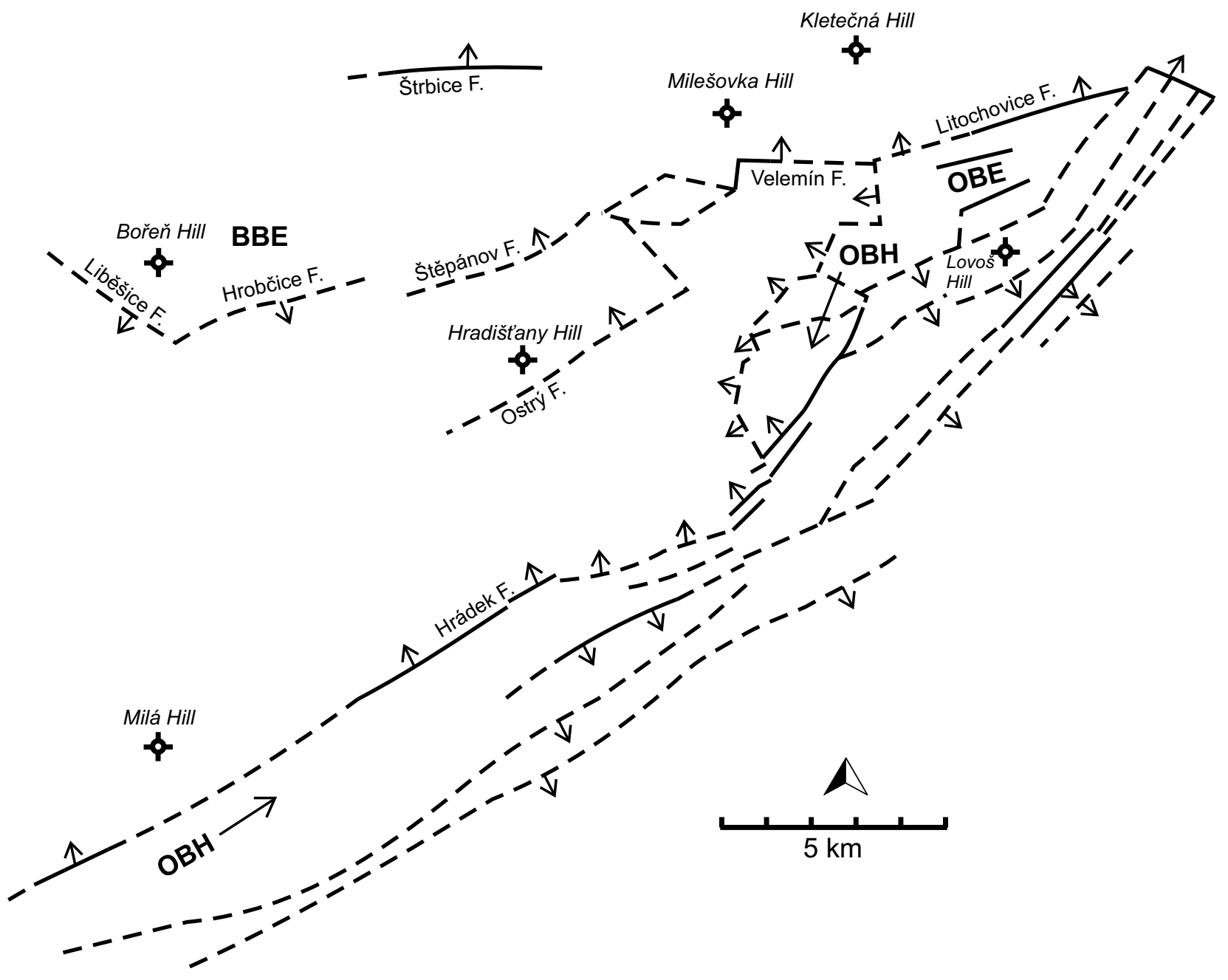

Fig. 5 "A" faults - post-Cretaceous/pre-volcanic, older than $36 \mathrm{Ma}$. Arrows - time-constrained relative vertical movement of blocks; arrow in the subsided block.

B) intravolcanic faults (Fig. 6) - younger than the Ústí and Děčín formations of the CSVC. Unfortunately, no accurate relationships are known between the faulting and the Dobrná Fm. volcanics. The age of these faults can be therefore supposed to be less than $24 \mathrm{Ma}$. This corresponds well with the idea of tectonic remobilization necessary for the Dobrná Fm. (24-19 Ma) magma ascent (Cajz 2000). It is important that the movements of this time were dominated by relative subsidence of northern blocks (NW to NE). The deeply subsided volcanic block near Bukovice was formed contemporaneously. It includes lahars and lavas of the Děčín Fm. composite volcano, exceptionally far from the central part of the complex. The E-W-oriented strike-slip movements, both right- and left-lateral, can be observed in older volcanics but their age may be younger. The most prominent among them is the Vaňov Fault. Tectonic reversals were found at the Štěpánov and Hrobčice faults. Movements on the
Štrbice F. continued with the subsidence of northern block at this time.

C) post-depositional / post-volcanic faults (Fig. 7) disrupting and/or limiting the basin fill and possibly younger than the Late Miocene volcanism (13-9 Ma). Faults activated at this time only accentuate the block setting. Smaller graben-like structures (HabrovanyŘehlovice and Lužice-Jánský faults) and horst-like structures (Nechvalice-Bystřany faults) were formed nearly perpendicular to the general graben course. Some of the movements were of opposite sense relative to older ones. This is most significant at the Žalany F., where the fault limited the deeply subsided Bukovice Block from the NE and subsequently determined the area of basinal sedimentation from the SW. The Štrbice F. was activated again. Demonstrably youngest are the last movements on the Ostrý F., which separates two blocks - one with a relict of a cinder cone and its vent, and another one with 


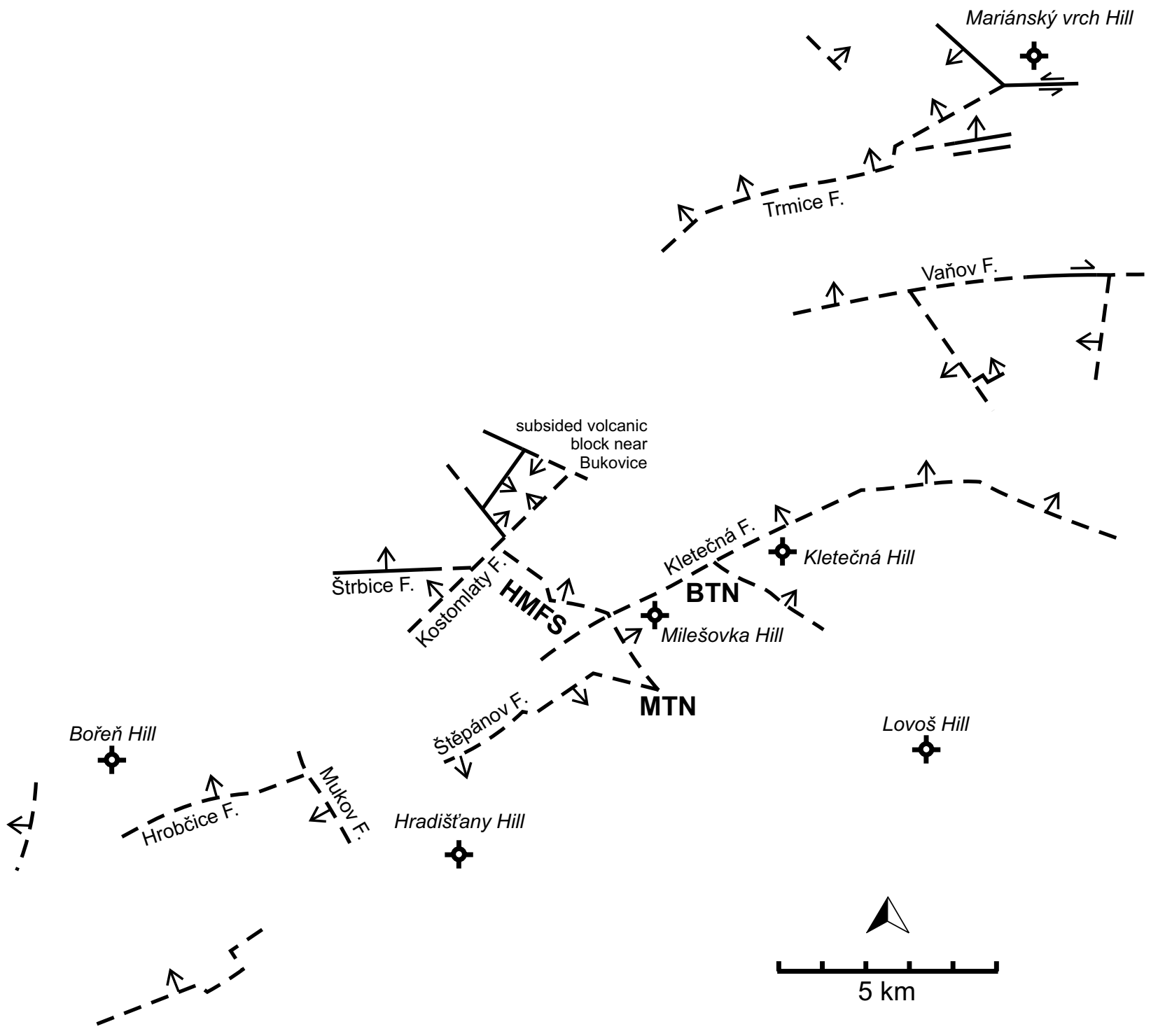

Fig. 6 "B" faults - syn-volcanic, younger than 24 Ma. Arrows - time-constrained relative vertical movement of blocks; arrow in the subsided block.

lava belonging to this vent. The uplifted NW block was detected due to the excessively high base of lava (Cajz et al. 2009) and verified by boreholes reaching different lithological boundaries in Cretaceous sediments. The age of the movements on faults of this group is less than $16 \mathrm{Ma}$, and possibly younger than the Strbice Fm. volcanics $-9 \mathrm{Ma}$ (at least at some of the faults).

\section{Discussion}

The above presented age categories of faults are based on the recognized movements on each of them; they represent time ranges with verified uppermost age constraint recorded in the current geological setting. As the topmost units have been eroded from the study area, there may have existed younger movements on these faults than those used for their age assignment. To be sure about the precise age constraints, study and evaluation of smallscale brittle tectonic phenomena is needed. A field survey itself cannot be used for the determination of the paleostress tensor during the fault activation. Nevertheless, the function of faults can be compared with the paleostress field reported to be in operation at the given time:

Our A-faults (post-Cretaceous/pre-volcanic; older than $36 \mathrm{Ma}$ - see Fig. 5) coincide in time with tectonic phases $\boldsymbol{\beta}_{1}$ and $\boldsymbol{\alpha}_{2}$ of Adamovič and Coubal $(1999,2009)$. Since the dip orientations of the fault planes could not be 


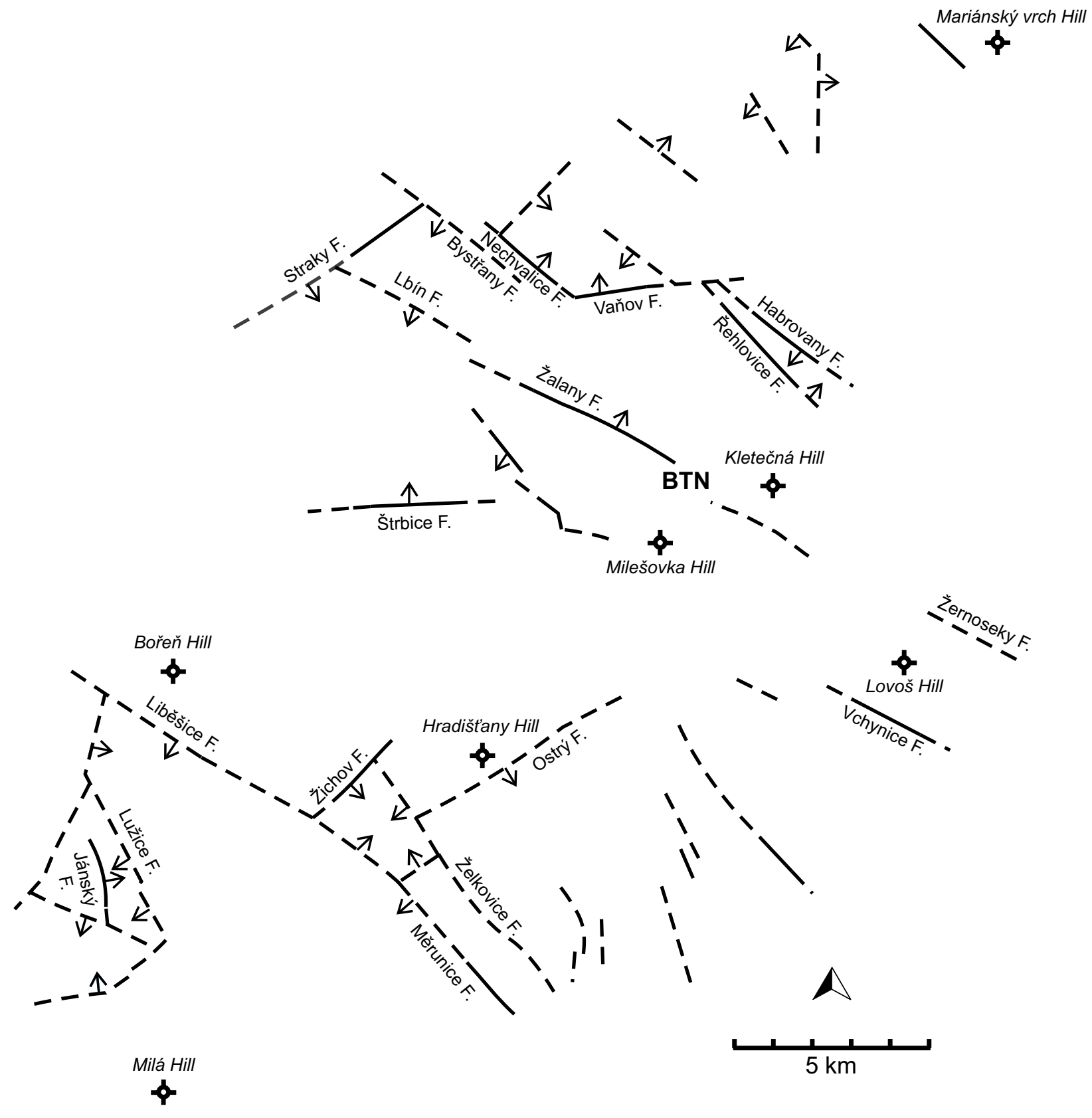

Fig. 7 "C" faults - post-depositional/post-volcanic, younger than $16 \mathrm{Ma}$ (possibly $9 \mathrm{Ma}$ ). Arrows - time-constrained relative vertical movement of blocks; arrow in the subsided block.

studied in the field, their kinematics (normal vs. reverse faulting) could not be determined. Nevertheless, their preferred WSW-ENE to SW-NE strikes demand nearly perpendicular orientation of stress in both cases. Then, only $\boldsymbol{\alpha}_{2}$ can be applied, which would imply a reverse movement under NNW-SSE compression. Then, no extension can be expected on the CSFZ during upwelling, and the upwelling itself is questionable. From this point of view, the riftogenic model is difficult to apply. A better explanation is that the CSFZ formation resulted from the stress relaxation after the $\boldsymbol{\alpha}$ compressive stress fields. This idea would apply an orientation of this tensor in a $\mathrm{N}-\mathrm{S}$ or, even better, NNW-SSE direction, which is slightly different from what has been published. The ascent of primitive basaltic magmas (Ústí Fm.) would have been the most easily achieved under extensional conditions.

B-faults (intravolcanic; younger than $24 \mathrm{Ma}$ - see Fig. 6) mostly coincide with $\boldsymbol{\beta}_{3} \mathrm{NW}-\mathrm{SE}$ extension, and some of them may be slightly older to coincide with $\boldsymbol{\beta}_{2}$ $\mathrm{N}-\mathrm{S}$ extension. No preferred orientation in their courses 
can be found. In extensional conditions, normal faults should develop. And extensional conditions are expected to allow the ascent of primitive magmas (Dobrná Fm.).

C-faults (post-depositional/post-volcanic; younger than $16 \mathrm{Ma}$ and some of them possibly than $9 \mathrm{Ma}$ - see Fig. 7) correspond in time to compressions $\boldsymbol{\gamma}$ and $\boldsymbol{\delta}$ (from nearly $\mathrm{E}-\mathrm{W}$ to $\mathrm{N}-\mathrm{S}$ ) or to the younger tensional field $\boldsymbol{\varepsilon}$ (Coubal and Adamovič 2000). The fault strikes are predominantly transverse to the graben axis and the constitution of smaller horst- and graben-like structures is characteristic. Formation of these structures is possible under the supposed stress field. The mostly short faults transverse to the CSFZ and causing its segmentation may belong to this fault group. Their strike is parallel to the dominant strikes of faults in the graben interior at this time. Compressional fields $\boldsymbol{\gamma}$ and $\boldsymbol{\delta}$ could have produced both sinistral and dextral strike-slip movements on the transverse faults.

Exceptional is the Štrbice F. which was active in the same style (subsidence of $\mathrm{N}$ block) during all periods and during all paleostress fields. Normal movements on this fault are obvious, which corresponds with $\boldsymbol{\beta}_{1}, \boldsymbol{\beta}_{2}$ and $\boldsymbol{\beta}_{3}$ fields but not with $\boldsymbol{\alpha}_{2}$ and $\boldsymbol{\gamma}-\boldsymbol{\delta}$ fields.

All the E-W-striking faults in the study area are of behavior distinct from those in the MB sedimentary fill. In the opinion of Rajchl et al. (2009), these faults in the MB belong to the older generation, having been overprinted by NE-SW-striking structures. Our results show a different situation: the $\mathrm{E}-\mathrm{W}$ faults are not overprinted by the NE-SW ones. The CSFZ (NE-SW) in the study area represents some kind of a structural barrier for the E-W faults because it was not affected by their activity. A similar situation is displayed at the termination of the Strbice F. (E-W) at the Kostomlaty F. (NE-SW) inside the graben. On the other hand, the Strbice F. and the Velemín F. belong among the oldest faults, as determined by the onset of their activity. Both faults are spatially connected with the basement ridges.

We suppose that the faults striking NW-SE are more important than assumed in the area of the MB (Rajchl et al. 2009). They belong among the youngest, they limit the basinal sediments and they constitute small grabens and horsts. Some of them were probably active under a tensional stress field $\varepsilon$. In case they overprint the older faults, then they are definitely not E-W faults, but NWSE faults.

\section{Conclusions}

The České středohoří Fault Zone (CSFZ) is only roughly parallel to the graben axis. The CSFZ consists of a system of parallel faults transected by younger strike-slip faults. Along the parallel faults, southeasterly blocks subsided; the highest blocks are concentrated to the northern part of the CSFZ and constitute here the horst (OBH). The CSFZ has not a direct relationship to the presumed "Deepseated Litomérice Fault", the supposed rift margin. The existence of a morphological ridge in the basement (OBE-BBE) played a more important role during the origin of the CSFZ than a simplified course of the Variscan terrane boundary between the Saxothuringian and TepláBarrandian zones. It is also possible that the tectonic setting in the basement itself is much more complicated. We suppose a post-Cretaceous/pre-volcanic formation of the CSFZ. Its origin may have been associated with a possible upwelling under a tensional paleostress field (using the riftogenic model). A change in the paleostress field was necessary for the transverse segmentation of the CSFZ. The expected largest vertical displacement magnitude is not parallel to the graben course and again, it is closely connected with the pre-existing basement ridges (OBE, BBE). Moreover, the maximum vertical displacement is reached over a relatively short distance (at the $\mathrm{N}$ margin of the OBE) or, more frequently, the displacement magnitude is split to several faults of different strikes in the graben interior.

In geomorphological subdivision, the CSVC is a composite regional geological unit with different settings in its central part (Milešov and Verneřice areas) and the part around Louny. This is reflected in the CSVC development as well. The Dobrná Fm. volcanics are preserved to a higher degree compared to the Ústí Fm. ones in the Louny marginal area. Volcanic activity in this part of the CSVC seems to be younger on average.

In the study area, faults in the graben interior are of variable strike. They constitute an irregular network consisting of rhomboidal blocks, very much like in the central part of the CSVC. The usual vertical displacement reaches tens of meters; it exceeds one hundred meters on several faults only. Repeated movements on some of faults were documented, both of the same sense or inverse ones. Two tectonic nodes, i.e. complicated fault intersections with the break-up of one large dip-slip into several smaller sectional ones, were defined (KTN, BTN). Also the complicated structure of the HMFS, representing wider zone interconnecting two zones of large vertical movement, was observed. These structures were spatially connected with the ridges in the basement.

The E-W-striking faults are not as frequent as described in the MB, and their age seems to be intravolcanic or younger. The Štrbice and the Velemín faults, both connected to the older structures in the basement and activated several times, may be of older origin. The E-W-striking faults do not offset the CSFZ course. This is in contradiction with the idea of their importance, activity and age in the MB. Nevertheless, faults of this strike show some of the highest magnitudes of relative 
subsidence of northern blocks in total. This may reflect an $\mathrm{E}-\mathrm{W}$ oriented interconnection of basement ridges (OBE and BBE), which was significant for graben formation. In the internal part of the graben, this inherited structure separates the northern area ( $\mathrm{N}$ to ENE) of large subsidence with large volumes of volcanic products from the southern area (S to WSW) with a dish-shaped shallow basin and probably primarily reduced volcanic activity.

Acknowledgements. This study was supported by the Grant Agency of the Academy of Sciences CR, Project No. IAA300460602 and falls within the Academic Research Plan AV0Z 30130516 of the Institute of Geology AS CR v.v.i. and Research Plan MZP 0002579801 of the Czech Geological Survey. The study was also partly supported by the Czech Science Foundation (205/07/0691). The new geological map involves results of three projects supported by the Ministry of Environment CR: ISPROFIN 215124-1, OH-18/01 (OG MŽP), PPŽP 630/1/97. The authors wish to acknowledge Karel Mach (Doly Bílina a.s.) and Jan Blín (Coal Services - former Mostecká uhelná a.s.) for tectonic data acquired during mining activities. Special thanks are due to Anna Trubačová for her great help with all figures, including the map. We also thank the two reviewers, Bedřich Mlčoch and Klaus Stanek, whose comments improved the manuscript significantly, and Jiří Adamovič and Vojtěch Janoušek for the language revision of the text.

At the end of this paper, allow the authors to commemorate Mr. Miroslav Váně, an outstanding expert in the geology and the tectonic structure of the Louny region, whose death in the early summer of this year was a sad loss for geology. This article draws on his findings and in many respects follows on from them. The authors would therefore like to devote this paper to the memory of Mr. Váně.

\section{References}

Adamovič J, Coubal M (1999) Intrusive geometries and Cenozoic stress history of the northern part of the Bohemian Massif. Geolines 9: 5-14

Adamovič J, Coubal M (2009) Time succession of Cenozoic stress fields in the northern part of the Bohemian Massif. In: RöHLing HG, LinNEMANN U, LANGE JM (eds) GeoDresden 2009 - Geologie der Böhmischen Masse, Kurzfassungen der Vorträge und Poster/Abstracts. Schriftreihe Dt Ges Geowiss 63: 269

Brus Z, Hurní S (1988) Faults in the North-Bohemian Brown Coal Basin: the review. In: PEŠEK J, VozÁR J (eds) Coal-bearing Formations of Czechoslovakia. Thematic Volume Concerning IGCP Project 166. Dionýz Štúr Institute of Geology, Bratislava, pp 103-109
CAJZ V (2000) Proposal of lithostratigraphy for the České středohoří Mts. volcanics. Bull Czech Geol Surv 75: 7-16

Cajz V, Adamovič J, Rapprich V, Valigurskí L (2004) Newly identified faults inside the volcanic complex of the České středohoří Mts., Ohře/Eger Graben, North Bohemia. Acta Geodyn Geomater 134: 213-222

Cajz V, Rapprich V, Erban V, Pécskay Z, Radoñ M (2009) Late Miocene volcanic activity in the České středohoří Mountains, Ohře (Eger) Graben, northern Bohemia. Geol Carpath 60: 519-533

СнА́в J (2008) Brief Geology of the Basement of Bohemian Massif and its Carboniferous and Permian Cover. Czech Geological Survey, Prague, pp 1-283 (in Czech)

Coubal M, Adamovič J (2000) Youngest tectonic activity on faults in the SW part of the Most Basin. Geolines 10: $15-17$

ČECH S, VALEČKA J (1991) Important transgressions and regressions in the Bohemian Cretaceous Basin. Unpublished manuscript, Czech Geological Survey, Prague, pp 1-51 (in Czech)

ČeCh S, Klein V, Ǩ̌íž J, ValečKa J (1980) Revision of the Upper Cretaceous stratigraphy of the Bohemian Cretaceous Basin. Věst Ústř Úst geol 55: 277-296 (in Czech)

Dèzes P, Schmid, SM, Ziegler PA (2004) Evolution of the European Cenozoic Rift System: interaction of the Alpine and Pyrenean orogens with their foreland lithosphere. Tectonophysics 389: 1-33

HAASE KM, RENNO AD (2008) Variation of magma generation and mantle sources during continental rifting observed in Cenozoic lavas from the Eger Rift, Central Europe. Chem Geol 257: 195-205

Herčík J, Herrmann Z, ValečKa J (2003) Hydrogeology of the Bohemian Cretaceous Basin. Czech Geological Survey, Prague, pp 1-91

HiBsch JE (1924) Erläuterungen zur geologischen Karte der Umgebung von Bilin. Státní geologický ústav Československé republiky, Prague, pp 1-148

HiBSCH JE (1926) Erläuterungen zur geologischen Übersichtskarte des Böhmischen Mittelgebirges und der unmittelbar angrenzenden Gebiete zugleich in allgemein verständlicher geologischen Führer. Freier Lehrerverein, Děčín, pp 1-143

Hurník S, Havlena V (1984) The Krušné hory Mts. and brown-coal basin at their foot as a part of a neotectonic megafold structure. Čas Mineral Geol 29: 55-67 (in Czech)

KopeCKÝ L (1974) Detection of faults and determination of their order in the region of platform volcanism. Sbor geol Věd, Geol 26: 197-226

KoPECKÝ L (1978) Neoidic taphrogenic evolution and young magmatism of the Bohemian Massif. Sbor geol Věd, Geol 31: 91-107

KoPeCKÝ L ed (1990) Explanatory text to the basic geological map of ČSSR $1: 25$ 000, sheet 02-341 Bílina. Czech Geological Survey, Prague, pp 1-112 (in Czech) 
Kycl P, Rapprich V, Mlčoch B, ValečKa J, Zelenka P, Č́a P, Havlíček P, Holásek O, Hradecká L, ŠIMŮNeK $Z$ (2009) Documentation of the outcrops and geological phenomena along the highway D-8, section 0805 Lovosice-Rehlovice and their importance for the environmental factors. Unpublished manuscript, Czech Geological Survey, Prague, pp 1-22 (in Czech)

Malkovský M (1977) Important Faults in the Platform Cover of The N Part of the Bohemian Massif. Czech Geological Survey, Prague, pp 1-30 (in Czech)

Malkovský M (1979) Tectogeny of the Platform Cover of the Bohemian Massif. Czech Geological Survey, Prague, pp 1-176 (in Czech)

Malkovský M (1987) The Mesozoic and Tertiary basins of the Bohemian Massif and their evolution. Tectonophysics 137: 31-42

MLČOCH B ed. (2001) Research on the crystalline formations in the deep basement of the Doupovské hory Mts. Complex and its surroundings. Unpublished manuscript, Czech Geological Survey, Prague, pp 1-121 (in Czech)

MLČOCH B (2003) Correlation of the crystalline basement outcropping in the Porta Bohemica with Saxothuringian Unit. Zpr geol Výzk v Roce 2002: 31-32 (in Czech)

Mlčoch B, KonopÁseK J (2010) Pre-Late Carboniferous geology along the contact of the Saxothuringian and Teplá-Barrandian zones in area covered by younger sediments and volcanics (western Bohemian Massif, Czech Republic). J Geosci 55: 81-94

MüLlER B (1924) Geologische Sektion Niemes-Roll (Kartenblatt Böhmisch Leipa-Dauba). Sbor St geol Úst Čs republ 4: 231-288

PeŠEK J (1996) Geology of the Upper Paleozoic basins in the Central Bohemia. Czech Geological Survey, Prague, pp 1-95 (in Czech)

Rajchl M, UličnÝ D, Grygar, R, Mach K (2009) Evolution of basin architecture in an incipient continental rift: the Cenozoic Most Basin, Eger Graben (Central Europe). Basin Res 21: 269-294

ŠEbesta J, Moravcová O, Cajz V, ValečKa J, Adamovič J, Kadlec J, Hroch Z, Burda J (1997) Slope movement hazards in the Labe (Elbe) River valley, Ústí nad Labem county. Unpublished manuscript, Czech Geological Survey, Prague, pp 1-62 (in Czech)

ŠŤovíčKovÁ N (1973) Deep-seated Tectonics and its Relation to Endogenic Geologic Processes. Academia, Prague, pp 1-198 (in Czech)

UličnÝ D, Laurin J, Čech S (2009a) Controls on clastic sequence geometries in a shallow-marine transtensional basin: the Bohemian Cretaceous Basin, Czech Republic. Sedimentology 56: 1077-1114

UličnÝ D, ŠpiČÁKová L, Grygar R, Svobodová M, ČeCH S, LAurin J (2009b) Palaeodrainage systems at the basal unconformity of the Bohemian Cretaceous Basin: roles of inherited fault systems and basement lithology during the onset of basin filling. Bull Geosci 84: 577-610

Ulrych J, Novák JK, Langrová A, Melka K, Cajz V, Adamovič J, Pertlik F, Wiesner T, ŽId L, Radoň M (2000) Tertiary phonolite laccolith of Mariánská hora Hill, N. Bohemia: Geological, petrological and mineralogical characteristics. Acta montana Series A 116: 5-44

VALEČKA J (1989) Sedimentology, stratigraphy and cyclicity of the Jizera Formation (Middle-Upper Turonian) in the Děčín area (N Bohemia). Věst Ústř Úst geol 64: 77-90

VALEČKa J (1990) Tectonic structures of the Upper Cretaceous rocks. In: HRADECKÝ P (ed) Geological-Tectonic Evaluation of the Nuclear Power Plant North Bohemia - the Building Site Choice. Unpublished manuscript, Czech Geological Survey, Prague, pp 8-14 (in Czech)

VAlEČKA J, ZELENKA P (2008) Stratigraphy, lithology and tectonics of Cretaceous sediments in the surroundings of Bílina. Zpr Stud Reg Muz (Teplice) 27: 85-93 (in Czech)

ValečKa J, Cajz V, Kycl P, MlČoch B, Rapprich V, ValigurSKÝ L, ZELENKA P (2003) Slope movement hazards in the SE part of the České středohoří Mts., in the Litoměřice region. Part B -Geology, geological map. Unpublished manuscript, Czech Geological Survey. Prague, pp 1-36 (in Czech)

ValečKa J, Cajz V, Rapprich V, Zelenka P, MlČoch B (2008) Geology, geological map and explanations (Documentation and specialized survey on slope movements - the České středohoří Mts. region, 2004-2007). Unpublished manuscript, Czech Geological Survey, Prague, pp 1-28 (in Czech)

VÁNĚ M (1985) The geological structure of the Krušné horypiedmont Graben and its tectonogenesis. Sbor Geol Věd, Geol 40: 147-181 (in Czech)

VÁNĚ M (1999) Geology of the Louny Area for the Third Millennium. Edited by the author, Chomutov, pp 1-476 (in Czech)

Vejlupek M (1984) Permo-Carboniferous in the basement of the Cretaceous NE of Litoměřice. Věst Ústř Úst geol 59: 173-177 (in Czech)

VeJlupeK M, NovÁK J (1986) Tectonics of the platform sediments in the Úštěk region. Věst Ústř Úst geol 61: 103-107 (in Czech)

Vejlupek M, KaAs A (1986) Tectonic structure of the Cretaceous of the Roudnice area. Čas Mineral Geol 31: 279-284 (in Czech)

WiLson M, Downes H (1991) Tertiary-Quaternary extension-related alkaline magmatism in Western and Central Europe. J Petrol 32: 811-849

ZahÁlka Č (1914) Cretaceous System in the České středohoří Mts. Edited by the author, Roudnice, pp 1-465 (in Czech)

ZIEGLER PA (1992) European Cenozoic rift system. Tectonophysics 208: 91-111 
